Plant Tissue Cult. \& Biotech. 25(1): 37-50, 2015 (June)

$\overline{\text { PTC\&B }}$

\title{
Effect of Silver Nitrate and Amino Acids on High Frequency Plants Regeneration in Barley (Hordeum vulgare $\mathbf{L}$.
}

\author{
Mozidul Haque, Abu Baker Siddique and S. M. Shahinul Islam* \\ Plant Genetic Engineering Laboratory, Institute of Biological Sciences, University of \\ Rajshahi, Rajshahi-6205, Bangladesh
}

Key words: Barley, Immature embryos, Somatic embryogenesis

\begin{abstract}
Three Bangladeshi barley genotypes viz. BARI barley-1, 3 and 6 were selected for this study to evaluate the efficiency of callus induction and plant regeneration. The effect of five doses of $\mathrm{AgNO}_{3}$ singly, and combined with amino acids (Lproline, L-glutamine) on callus induction and plant regeneration efficiency was evaluated using BARI barley-3 and 6. The maximum values of callus induction were recorded at 49.20 and $32.66 \%$ for BARI barley- 6 and 3, respectively when $2.0 \mathrm{mg} / \mathrm{l} \mathrm{AgNO}_{3}$ and $200 \mathrm{mg} / \mathrm{l} \mathrm{L-glutamine}$ were added to the callus induction medium. Moreover, plant regeneration remarkably increased on MS $+1.0 \mathrm{mg} / \mathrm{l}$ $\mathrm{BAP}+1.5 \mathrm{mg} / \mathrm{l} \mathrm{AgNO}_{3}+150 \mathrm{mg} / \mathrm{l} \mathrm{L-glutamine}$ as $37.20 \%$ in BARI barley- 6 and $16.13 \%$ in BARI barley-3. For rooting $\mathrm{AgNO}_{3}$ singly affect positively, whereas negative influence was observed in combinations with any amino acids. However, by using $\mathrm{AgNO}_{3}$ and amino acids, around $<4,<27$ and $<5$ fold increase in callus induction were obtained. Regeneration and rooting were also found to increase considerably.
\end{abstract}

\section{Introduction}

Barley (Hordeum vulgare L.) is an ancient, widely distributed cereal crop in the world and this crop also grows in Bangladesh. It is used for malt, feed, food and many commercially industrial foods manufacture. A reliable improvement of barley genotypes is needed to develop through in vitro culture that advantageous over traditional methods of propagation. It provides a source of standardized plant material for the analysis of plant metabolism and other cellular processes

*Author for correspondence: <shahin_ibsc@ru.ac.bd>. 
and responses (Taji et al. 1992). Orton (1979) reported that growth and development of barley in tissue culture, depends on media used in each phase, i.e. callus initiation, callus maintenance, and differentiation of callus into shoots and roots.

The efficiency of callus formation and plant regeneration depends on the donor plant material i.e. species or cultivars (Bregitzer 1992). Moreover, callus quality varied considerably among genotypes (Vasil and Vasil 1987, Islam 2010); and most barley varieties initiate friable and translucent callus (Hanzel et al. 1985, Ward and Jordan 2001, Chauhan and Kothari 2004). Bregitzer et al. (1998) also reported that the poor regeneration potential of modern cultivars is one current limitation of barley transformation. Besides, it is an essential approach in biotechnology to improve plant genotypes. Indian barley cultivars are often considered as less responsive to tissue culture due to poor callus induction, low frequency of embryogenesis and lesser percentage of plant regeneration (Chauhan and Kothari 2004). However, regeneration ability is strongly affected by several factors such as genotypes, developmental stages and composition of culture medium and type of explants in barley (Gubišová et al. 2012, Haque and Islam 2014) and rice (Siddique et al. 2014). Different explants are used to induce callus and subsequent regeneration, such as immature embryos (Chang et al. 2003), immature inflorescence (Havrlentova et al. 2001, mature embryo (Abumhadi et al. 2005, He and Jia 2008), coleoptile (Sahrawat and Chand 2004) and seedling parts (Sharma et al. 2004). Klčová et al. (2004) reported that donor plant quality and environmental conditions are also influenced biotechnological research. However, callus induction and plant regeneration potential is highly dependent upon the genotype, culture media and growth regulators in barley and other cereal crops (Goldstein and Kronstad 1986, Bhaskaran and Smith 1990, Islam et al. 2001, Chauhan and Kothari 2004, Gürel et al. 2009, Khatun et al. 2010). The medium containing BAP in combination with 2, 4-D showed the positive effect on regeneration in barley anther culture (Cho et al. 1998).

Recently, some reports have been mentioned that use of silver nitrate $\left(\mathrm{AgNO}_{3}\right)$ and/ or amino acids in media, plays an important role to improve callus induction, shoot and root formation in various plants; such as wheat (Wu et al. 2006, Bouiamrine et al. 2012), maize (El-Itriby et al. 2003), sorghum (Pola et al. 2009), pearl millet (Oldach et al. 2001) and Naga chilli (Sharma et al. 2008, Bora et al. 2014). Some authors also reported that regeneration can be improved by $\mathrm{AgNO}_{3}$ in both dicots and monocots (Kumar et al. 2009, Kabir et al. 2013). Hussein et al. (2004) examined that $\mathrm{AgNO}_{3}$ promotes callus formation and regeneration in barley. So far as it is known that there is not enough work has been done on Bangladeshi barley cultivars using biotechnological approach. 
Hence, this study has been conducted to provide a suitable and efficient protocol for callus induction and regeneration using $\mathrm{AgNO}_{3}$ and amino acids through immature embryos of barley in Bangladesh.

\section{Materials and Methods}

Mature seeds of three barley genotypes viz., BARI barley-1, 3, and 6 were collected from Bangladesh Agricultural Research Institute (BARI), Gazipur, Bangladesh and grown in the experimental field of the Institute of Biological Sciences, University of Rajshahi, Bangladesh. The seeds of milky phase, containing immature embryos were collected and used as explants.

Spikes, containing seeds of milky phase, approximately 14 - 16 days after anthesis were sterilized for $45 \mathrm{sec}$ using $70 \%$ ethanol in a laminar air flow cabinet. To induce callus the embryos were aseptically dissected from the seeds, and inoculated on callus induction medium CIM containing MS supplemented with different concentrations of 2, 4-D (1.0, 1.5, 2.0, 2.5 and $3.0 \mathrm{mg} / \mathrm{l})$. The inoculated Petri dishes were sealed and cultures were incubated in the dark chamber at $25 \pm 2^{\circ} \mathrm{C}$ for callus induction.

When the age of the calli was around three weeks, they were transferred to the regeneration medium ( $\mathrm{RM}=\mathrm{MS}+1.0 \mathrm{mg} / \mathrm{l} \mathrm{BAP}$ ) and cultured under low light conditions at $25 \pm 2{ }^{\circ} \mathrm{C}$ together with $14 / 10 \mathrm{hrs}$ (light/dark) photoperiods. The regenerated shoots length around $2-3 \mathrm{~cm}$ were transferred to root formation medium (RFM) that was GM (modified from MS, Islam 2000) + $1.0 \mathrm{mg} / \mathrm{l}$ IAA for better roots. The well developed rooted plantlets were transferred to pots, and acclimatized plants were transferred to field's growing up to maturity for seed collection.

To observe the effect of $\mathrm{AgNO}_{3}$ and amino acids (AA) on callus induction $(\mathrm{CI})$, plant regeneration (PR) and root formation (RF), five different concentrations of $\mathrm{AgNO}_{3}$ singly and combinations with L-proline and/or Lglutamine were added to related media as shown in Table 1 (CIM) and Table 2 (RM and RFM). The combinations were added to CIM for callusing, RM for regeneration and RFM for rooting. The media without $\mathrm{AgNO}_{3}$ and amino acids considered as control. Sucrose $(30 \%)$, gelling agent agar $(7 \%)$ were added to medium and $\mathrm{pH}$ adjusted 5.8.

The average or mean values were computed from five replicates with standard error (SE) and each experiment was repeated thrice. ANOVA and post hoc DMRT were done using SPSS 16.0 software. 


\section{Results and Discussion}

Five different concentrations of 2, 4-D were examined in three studied genotypes, and the results showed that BARI barley-6 performed with highest frequency of callus induction (13.86\%) in MS with $2.0 \mathrm{mg} / \mathrm{l} 2,4-\mathrm{D}$; followed by BRRI barley-3 (11.73\%) (Fig. 2). On the other hand the lowest value was recorded for the genotype of BARI barley-1. No callusing was found in control (without 2,4-D) for studied genotypes. The effect of 2,4-D levels on the genotypes showed significant difference at $\mathrm{p}<0.05$.
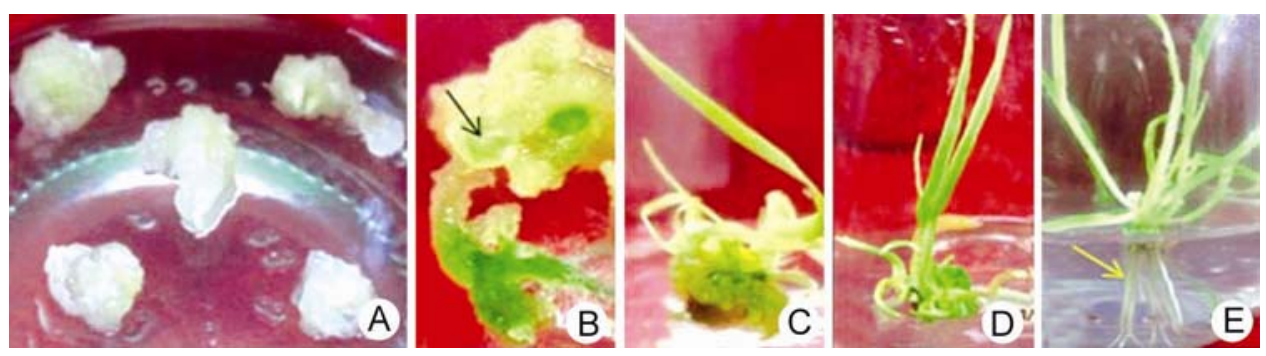

Fig. 1. Callus induction and plant regeneration of immature embryos of Hordeum vulgare. (A) callus induction after three weeks in CIM, (B) embryogenic callus and green spots, (C) developments of shoots, (D) well developed plantlet, (E) regenerated plants with good root and shoots.

Castillo et al. (1998) successfully regenerated plants at earlier through in vitro system in barley. Zapata et al. (2004) optimized 2,4-D levels as $2.0 \mathrm{mg} / \mathrm{l}$ and reported approximately similar results on callus induction using mature embryos of barley. The same level of 2,4-D (2.0 mg/l) gave the best response in maize (Jakubeková et al. 2011), wheat (Pourmohammad 2013) and chickpea (Zaman et al. 2010) which were also similar to our findings. Some studies have shown that 2,4-D is an important factor for callus initiation and proliferation of primary and embryogenic callus from immature embryos in maize (Carvalho et al. 1997, Manivannan et al. 2010). However, in the present investigation, 1.46 to $13.86 \%$ callus induction was recorded. The wide range of variability might be occurred due to genotypic effect along with the different levels of 2, 4-D. It has been reported that the frequency of callus induction, friability of embryogenic calli and regeneration are influenced by genotype, culture media and genotype $\times$ culture media interaction in barley (Bregitzer et al. 1998, Manoharan and Dahleen 2002), maize (Zhu 2011, Jakubeková et al. 2011), wheat (Farshadfar 2014, Islam et al. 2001), rice (Siddique et al. 2014, Sah and Kaur 2013), citrus (Gholami et al. 2013), sorghum (Indra and Krishnaveni 2009) and pearl millet (Jha et al. 
2009). However, it could be suggested that among the 2,4-D levels (1.0-3.0 mg/l) tested, middle concentrations are comparatively better than lower and higher ones for callus induction in barley.

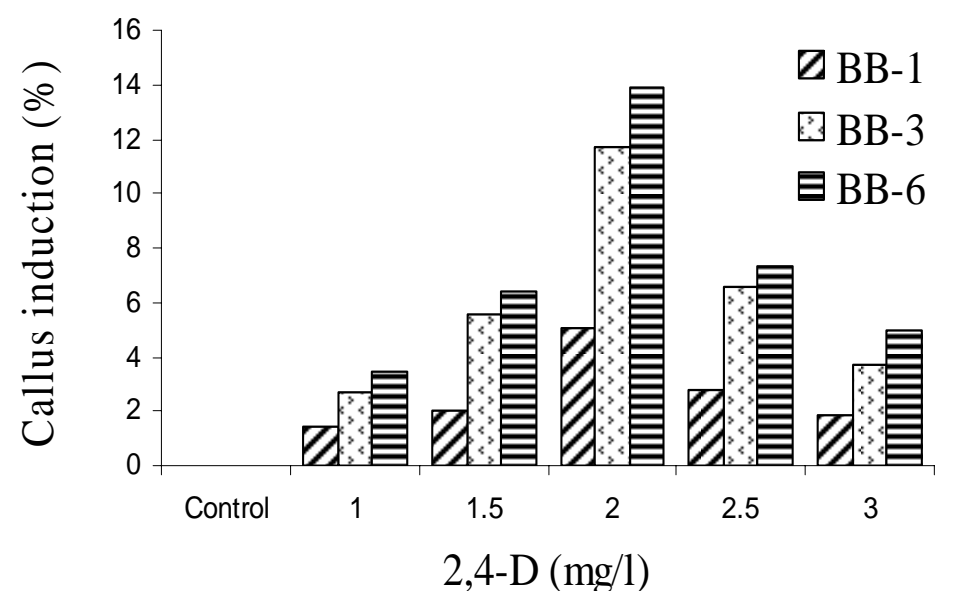

Fig. 2. Comparison of callus induction using different concentration of $2,4-\mathrm{D}(\mathrm{p}<0.05)$.

Five different concentrations of $\mathrm{AgNO}_{3}$ singly and/or combined with five levels of L-proline or L-glutamine were tested, and the highest frequency of

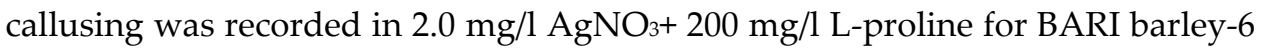
(49.20\%); followed by BARI barley-3 (32.66\%) in the same $\mathrm{AgNO}_{3}$ and amino acid concentration (Table 1). The lowest value was recorded in BARI barley-3 $(9.86 \%)$ when the explants were cultured on $2.5 \mathrm{mg} / \mathrm{l} \mathrm{AgNO}_{3}+125 \mathrm{mg} / \mathrm{l} \mathrm{L}$-proline +125 $\mathrm{mg} / \mathrm{l} \mathrm{L-glutamine.} \mathrm{Whereas,} \mathrm{the} \mathrm{frequencies} \mathrm{of} \mathrm{callus} \mathrm{induction} \mathrm{were} 11.20$ and $13.24 \%$ for BARI barley-3 and BARI barley-6 in control medium, respectively. The recorded highest values were around four-folds higher than the control of BARI barley- 6 and three-folds for BARI barley-3.

Fernandez et al. (1999) recorded enhanced frequency from immature embryo culture in durum wheat at large scale using $\mathrm{AgNO}_{3}$. Chauhan and Kothari (2004) reported that Indian barley cultivars are often considered as less responsive to tissue culture due to poor callus induction, low frequency of embryogenesis and lesser percentage of plant regeneration. In our investigation, Bangladeshi barley cultivars also showed poor callusing in control conditions which can be overcome by addition of $\mathrm{AgNO}_{3}$, L-proline and L-glutamine to callus induction medium at recommended above levels. Furthermore, different levels and combinations showed significantly different effects to studied barley cultivars. In previous report, it was suggested that concentrations of $\mathrm{AgNO}_{3}$ is strongly 
depended on species and genotypes (Cristea et al. 2012, Al-Khayri and AlBahrany 2004).

L-glutamine concentration had a noticeable effect in Eragrostis tef (Gugsa and Kumlehn 2011). However, most of the authors reported similar positive effect of $\mathrm{AgNO}_{3}$, proline and glutamine in various plants species; such as glutamine (Hunter 1987, Mordhorst and Lörz 1993), L-glutamine, casein hydrolysate and L-proline (Ganeshan et al. 2006), casein hydrolysate and L-proline (Chauhan et al. 2007), glutamine, L-asparagine and CH (Bi and Wang 2008), aspartic acid, glutamine, proline, tryptophan and casein hydrolysate (Yu et al. 2008) proline, glutamine and asparagine (Islam and Tuteja 2012, Haque and Islam 2014). On the contrary, an inhibitory effect of glutamine has been observed in the production of barley pollen callus by $\mathrm{Xu}$ and Sunderland (1981).

Different combinations of silver nitrate, L-proline and L-glutamine as mentioned earlier were tested, and maximum $37.20 \%$ plant regeneration was found in $1.5 \mathrm{mg} / \mathrm{l} \mathrm{AgNO}_{3}$ and $150 \mathrm{mg} / \mathrm{l} \mathrm{L}$-glutamine for BARI barley- 6 . The variety BARI barley-3 performed with the frequency of $16.12 \%$ in the same level of silver nitrate and amino acids (Table 2). However, it was found that presence of silver nitrate or/and amino acids affected plant regeneration and enhanced the performance of genotypes significantly. Purnhauser et al. (1987) first reported that $\mathrm{AgNO}_{3}(10.0 \mathrm{mg} / \mathrm{l})$ effectively promoted regeneration in wheat. In barley cultivar Morex, almost doubled regeneration was recorded using $\mathrm{AgNO}_{3}$, while 1.5-folds for Golden Promise (Jha et al. 2007). Moreover, addition of $\mathrm{AgNO}_{3}$ increased the frequency of plant regeneration significantly in various plants species such as Pearl millet (Oldach et al. 2001), Naga chilli (Bora et al. 2014, Sharma et al. 2008), wheat (Bouiamrine et al. 2012, Wu et al. 2006), maize (El-Itriby et al. 2003, Huang et al. 2004), sorghum (Pola et al. 2009). In our investigation around 27-folds higher regeneration was recorded in $1.5 \mathrm{mg} / \mathrm{l}$ $\mathrm{AgNO}_{3}$ and $150 \mathrm{mg} / \mathrm{l} \mathrm{L-glutamine}$ for BARI barley-6. Anantasaran and Kamnoon (2008) found almost similar results from Zinnia cultivars by adding $2.0 \mathrm{mg} / \mathrm{l}$ $\mathrm{AgNO}_{3}$. Gubišová et al. (2012) obtained improved regeneration and were observed significant differences in Slovak spring barley cultivars. On the contrary, no positive effect of $\mathrm{AgNO}_{3}$ on plant regeneration was found using immature embryos culture in barley by Hussein et al. (2004). Pua et al. (1999) suggested that $\mathrm{Ag}^{+}$might interfere with polyamines. Our observations argues with their reports and suggested that $\mathrm{AgNO}_{3}$ clearly affect the regeneration positively and addition of L-glutamine gives more better results especially at 1.5 $\mathrm{mg} / \mathrm{l} \mathrm{AgNO}_{3}$ and $150 \mathrm{mg} / \mathrm{l} \mathrm{L-glutamine}$.

Among the concentrations of $\mathrm{AgNO}_{3}$ individually added, maximum $13.06 \%$ regeneration was found in BARI barley- 6 at $3.0 \mathrm{~g} / \mathrm{l}$ level which was around ten- 
fold higher than the control (1.40\%). It was also observed that higher and lower concentrations than $3.0 \mathrm{~g} / \mathrm{l}$ of $\mathrm{AgNO}_{3}$, gave lower frequencies in both genotypes BARI barley-3 and BARI barley-6. Furthermore, addition of L-glutamine with $\mathrm{AgNO}_{3}$ gave remarkable higher results in comparison with control. By using glutamine as a nontoxic nitrogen source, higher frequency of green plants was obtained in barley genotypes (Olsen 1987). Islam (2000) and Islam and Tuteja (2012) found that $0.5 \mathrm{~g} / \mathrm{l} \mathrm{L-glutamine}$ significantly promoted shoot regeneration in wheat androgenetic research. Glutamine and and/or proline promotes plant regeneration in microspore cultures of rice (Cho and Zapata 1988, Ogawa et al. 1995). In barley, addition of complex amino acid mixture, improved the rate of androgenic plants production in barley (Ouédraogo et al. 1998).

Table 1. Effects of different concentrations and combinations of $\mathrm{AgNO}_{3}$ and amino acids on callus induction in immature embryos of two barley genotypes $(\% \pm \mathrm{SE})$.

\begin{tabular}{|c|c|c|c|}
\hline Supplements (mg/l) & NIE & BARI barley-3 & BARI barley- 6 \\
\hline Control & 100 & $11.20 \pm 0.58 \mathrm{a}$ & $13.24 \pm 0.81 \mathrm{a}$ \\
\hline \multicolumn{4}{|l|}{$\mathrm{AgNO}_{3}$} \\
\hline 1.0 & 150 & $12.40 \pm 0.91 c$ & $14.13 \pm 0.99 b c$ \\
\hline 2.0 & 150 & $13.06 \pm 1.02 \mathrm{~cd}$ & $15.86 \pm 1.01 \mathrm{~cd}$ \\
\hline 3.0 & 150 & $15.33 \pm 1.22 \mathrm{e}$ & $19.73 \pm 1.20 \mathrm{de}$ \\
\hline 4.0 & 150 & $14.26 \pm 1.10 \mathrm{de}$ & $17.06 \pm 1.10 \mathrm{~cd}$ \\
\hline 5.0 & 150 & $13.86 \pm 0.77 \mathrm{de}$ & $16.40 \pm 1.14 \mathrm{~cd}$ \\
\hline \multicolumn{4}{|l|}{$\mathrm{AgNO}_{3}+$ L-proline } \\
\hline $0.5+50$ & 300 & $15.93 \pm 1.40 \mathrm{e}$ & $17.33 \pm 0.89 \mathrm{~cd}$ \\
\hline $1.0+100$ & 300 & $16.80 \pm 1.07 \mathrm{ef}$ & $20.66 \pm 1.47 \mathrm{e}$ \\
\hline $1.5+150$ & 300 & $18.46 \pm 1.10 \mathrm{~g}$ & $23.86 \pm 1.83 f$ \\
\hline $2.0+200$ & 300 & $17.60 \pm 0.83 f g$ & $21.06 \pm 1.21 \mathrm{ef}$ \\
\hline $2.5+250$ & 300 & $16.86 \pm 0.67 f$ & $18.40 \pm 1.13 \mathrm{~d}$ \\
\hline \multicolumn{4}{|l|}{$\mathrm{AgNO}_{3}+\mathrm{L}$-glutamine } \\
\hline $0.5+50$ & 300 & $20.06 \pm 1.06 \mathrm{~h}$ & $21.53 \pm 3.31 \mathrm{ef}$ \\
\hline $1.0+100$ & 300 & $21.13 \pm 1.09 \mathrm{i}$ & $36.53 \pm 2.28 \mathrm{~h}$ \\
\hline $1.5+150$ & 300 & $23.20 \pm 1.79 j$ & $40.06 \pm 2.97 \mathrm{i}$ \\
\hline $2.0+200$ & 300 & $32.66 \pm 2.13 \mathrm{k}$ & $49.20 \pm 3.11 j$ \\
\hline $2.5+250$ & 300 & $19.13 \pm 0.95 \mathrm{gh}$ & $24.66 \pm 1.64 \mathrm{~g}$ \\
\hline \multicolumn{4}{|c|}{$\mathrm{AgNO}_{3}+$ L-proline + L-glutamine } \\
\hline $0.5+25+25$ & 150 & $14.80 \pm 0.82 \mathrm{de}$ & $17.73 \pm 0.80 \mathrm{~cd}$ \\
\hline $1.0+50+50$ & 150 & $16.53 \pm 1.18 \mathrm{ef}$ & $20.53 \pm 1.76 \mathrm{e}$ \\
\hline $1.5+75+75$ & 150 & $13.46 \pm 0.61 \mathrm{~d}$ & $16.26 \pm 1.43 \mathrm{~cd}$ \\
\hline $2.0+100+100$ & 150 & $12.13 \pm 1.12 b c$ & $15.06 \pm 0.83 c$ \\
\hline $2.5+125+125$ & 150 & $9.86 \pm 0.71 b$ & $12.13 \pm 0.71 b$ \\
\hline
\end{tabular}

NIE: Number of inoculated embryos. The values followed by different letters in a column are significantly different at $\mathrm{p}<0.05$ according to DMRT. 
Efficient regeneration of plants from embryogenic barley callus often is limited to specific genotypes that exhibit vigorous plant regeneration (Bregitzer et al. 1995, Przetakiewicz et al. 2003). In our study it was observed that addition of $\mathrm{AgNO}_{3}$ gave better performance than control $\left(\mathrm{AgNO}_{3}>\right.$ cont.). As such the influence of examined combinations could be recommended as ascending order i.e. $\left(\mathrm{AgNO}_{3}\right.$ and $\mathrm{L}$-glutamine $)>\mathrm{AgNO}_{3}>\left(\mathrm{AgNO}_{3}, \mathrm{~L}\right.$-proline and L-glutamine $)>$ (L-glutamine and L-proline) $>$ control, for plant regeneration through in vitro culture in barley.

Table 2. Regeneration response of immature embryos, prior to $\mathrm{AgNO}_{3}$ and amino acids of two barley genotypes $(\% \pm \mathrm{SE})$.

\begin{tabular}{lcccc}
\hline \multirow{2}{*}{$\begin{array}{c}\text { Supplements } \\
(\mathrm{mg} / \mathrm{l})\end{array}$} & BARI barley-3 & BARI barley-6 & BARI barley-3 & BARI barley-6 \\
\cline { 2 - 5 } Control & $0.80 \pm 0.20 \mathrm{a}$ & $1.40 \pm 0.24 \mathrm{a}$ & $2.46 \pm 0.35 \mathrm{~cd}$ & $3.40 \pm 0.35 \mathrm{bc}$ \\
\hline AgNO $_{3}$ & & & & \\
1.0 & $5.46 \pm 0.71 \mathrm{c}$ & $7.33 \pm 0.47 \mathrm{c}$ & $3.46 \pm 0.38 \mathrm{~d}$ & $5.86 \pm 0.757 \mathrm{~d}$ \\
2.0 & $6.93 \pm 0.90 \mathrm{~d}$ & $10.66 \pm 1.01 \mathrm{~d}$ & $6.13 \pm 0.64 \mathrm{f}$ & $9.60 \pm 0.95 \mathrm{e}$ \\
3.0 & $8.13 \pm 0.85 \mathrm{de}$ & $13.06 \pm 1.49 \mathrm{e}$ & $10.53 \pm 1.10 \mathrm{~g}$ & $15.73 \pm 1.69 \mathrm{f}$ \\
4.0 & $7.06 \pm 0.80 \mathrm{~d}$ & $11.73 \pm 1.14 \mathrm{de}$ & $4.26 \pm 0.61 \mathrm{e}$ & $6.40 \pm 0.65 \mathrm{~d}$ \\
5.0 & $6.26 \pm 0.68 \mathrm{~d}$ & $8.40 \pm 0.71 \mathrm{~cd}$ & $2.40 \pm 0.33 \mathrm{~cd}$ & $3.86 \pm 0.57 \mathrm{c}$ \\
AgNO + L-proline & & & \\
$0.5+50$ & $1.60 \pm 0.24 \mathrm{ab}$ & $2.66 \pm 0.43 \mathrm{ab}$ & $0.60 \pm 0.12 \mathrm{a}$ & $0.93 \pm 0.19 \mathrm{a}$ \\
$1.0+100$ & $2.13 \pm 0.42 \mathrm{ab}$ & $2.93 \pm 0.46 \mathrm{ab}$ & $0.93 \pm 0.19 \mathrm{ab}$ & $1.53 \pm 0.22 \mathrm{ab}$ \\
$1.5+150$ & $3.06 \pm 0.53 \mathrm{ab}$ & $4.13 \pm 0.77 \mathrm{~b}$ & $1.33 \pm 0.23 \mathrm{~b}$ & $2.06 \pm 0.28 \mathrm{~b}$ \\
$2.0+200$ & $2.26 \pm 0.37 \mathrm{ab}$ & $3.86 \pm 0.53 \mathrm{~b}$ & 0 & 0 \\
$2.5+250$ & $1.33 \pm 0.29 \mathrm{ab}$ & $2.13 \pm 0.34 \mathrm{ab}$ & 0 & 0 \\
AgNO + L-glutamine & & & \\
$0.5+50$ & $9.46 \pm 1.42 \mathrm{ef}$ & $15.26 \pm 1.28 \mathrm{f}$ & $0.73 \pm 0.19 \mathrm{a}$ & $1.33 \pm 0.23 \mathrm{a}$ \\
$1.0+100$ & $12.06 \pm 1.09 \mathrm{~g}$ & $24.93 \pm 2.46 \mathrm{~g}$ & $1.06 \pm 0.28 \mathrm{ab}$ & $2.46 \pm 0.47 \mathrm{~b}$ \\
$1.5+150$ & $16.13 \pm 1.34 \mathrm{~h}$ & $37.20 \pm 2.19 \mathrm{i}$ & $2.13 \pm 0.50 \mathrm{c}$ & $3.40 \pm 0.35 \mathrm{bc}$ \\
$2.0+200$ & $10.66 \pm 1.01 \mathrm{f}$ & $28.46 \pm 2.76 \mathrm{~h}$ & $0.66 \pm 0.18 \mathrm{a}$ & $1.06 \pm 0.19 \mathrm{a}$ \\
$2.5+250$ & $8.40 \pm 0.92 \mathrm{e}$ & $12.53 \pm 1.25 \mathrm{e}$ & 0 & 0 \\
AgNO + L-proline $+\mathrm{L}-$ glutamine & & & 0 \\
$0.5+25+25$ & $3.73 \pm 0.54 \mathrm{bc}$ & $5.46 \pm 0.77 \mathrm{bc}$ & $1.73 \pm 0.33 \mathrm{bc}$ & $2.93 \pm 0.33 \mathrm{~b}$ \\
$1.0+50+50$ & $5.86 \pm 0.57 \mathrm{~cd}$ & $6.13 \pm 0.99 \mathrm{bc}$ & $0.93 \pm 0.16 \mathrm{ab}$ & $1.46 \pm 0.24 \mathrm{ab}$ \\
$1.5+75+75$ & $3.33 \pm 0.47 \mathrm{~b}$ & $4.13 \pm 0.57 \mathrm{~b}$ & 0 & 0 \\
$2.0+100+100$ & $2.26 \pm 0.33 \mathrm{ab}$ & $3.06 \pm 0.33 \mathrm{ab}$ & 0 & 0 \\
$2.5+125+125$ & $1.73 \pm 0.45 \mathrm{ab}$ & $2.93 \pm 0.49 \mathrm{ab}$ & 0 & 0 \\
\hline & & & & 0 \\
\hline
\end{tabular}

The values followed by different letters in a column are significantly different at $\mathrm{p}<0.05$ according to DMRT.

Concentrations and combinations of $\mathrm{AgNO}_{3}$ and amino acids as mentioned previously were also examined for root induction; and the maximum frequency 
of rooting (10.53\%) was obtained in $3.0 \mathrm{mg} / \mathrm{l} \mathrm{AgNO}_{3}$ for BARI barley-3 and $15.73 \%$ for BARI barley- 6 in the same concentration of $\mathrm{AgNO}_{3}$ (Table 2). No significant effect was observed in rooting compared to controls when amino acids were added with $\mathrm{AgNO}_{3}$. Moreover, in some cases, especially in higher concentrations of and $\mathrm{AgNO}_{3}$ and amino acids no root induction was found in both genotypes. Present findings agreed well with the reports as noticed in Rotula aquatica (Lour) where $2.67 \mathrm{mg} / \mathrm{l}$ of silver nitrate gave the improved frequency of rooting (Sunandakumari et al. 2004). Kumar et al. (2009) and Reddy et al. (2001) also observed that the positive effect of $\mathrm{AgNO}_{3}$ for root formation in barley genotypes. They obtained higher values of rooting frequency using 9.12 $\mathrm{mg} / \mathrm{l}$ of $\mathrm{AgNO}_{3}$ in which elongation of roots were also increased. In present study, 2-5-folds increased rooting was recorded when $\mathrm{AgNO}_{3}$ was individually added in various concentrations to rooting medium. On the contrary, the efficiency of $\mathrm{AgNO}_{3}$ to influence the root induction was reduced when any amino acids were combined with $\mathrm{AgNO}_{3}$. Silva et al. (2011) mentioned that although the effect of $\mathrm{AgNO}_{3}$ is not well understood, it is supposed that the silver ion binds a possible ethylene receptor at the plasma membrane, thus inhibiting the binding of ethylene to this receptor and consequently triggering the specific action of the hormone.

\section{Acknowledgements}

The authors gratefully acknowledge to the authorities of the Institute of Biological Sciences, University of Rajshahi for providing research facilities and the University Grant Commission (UGC) of Bangladesh for providing fellowships for this study.

\section{References}

Abumhadi N, Kamenarova K, Todorovska E, Dimov G, Trifonova A, Gecheff K and Atanassov A (2005) Callus induction and plant regeneration from barley mature embryos (Hordeum vulgare L.). Biotech. Biotechnol. Eq. 19(3): 32-38.

Al-Khayri JM and Al-Bahrany AM (2004) Genotype dependent in vitro response of date palm (Phoenix dactylifera L.) cultivars to silver nitrate. Scientia Hort. 99(2): 153-162.

Anantasaran J and Kamnoon K (2008) Influence of medium formula and silver nitrate on in vitro plant regeneration of Zinnia cultivars. Songklanakarin J. Sci. Technol. 30(1): $1-6$.

Bhaskaran S and Smith RH (1990) Regeneration in cereal tissue culture: A review. Crop Sci. 30: 1328-1336.

Bi R and Wang H (2008) Primary studies on tissue culture from mature embryos in diploid and tetraploid wheat. Front. Agr. China 2: 262-265. 
Bora G, Gogoi HK and Handique PJ (2014) Effect of silver nitrate and gibberellic acid on in vitro regeneration, flower induction and fruit development in Naga Chilli. As Pac. J. Mol. Bio. Biotech. 22(1): 137-144.

Bouiamrine EH, Diouri M and El-Halimi R (2012) Somatic embryogenesis and plant regeneration capacity from mature and immature durum wheat embryos. Int. J. BioSci. 9(2): 29-39.

Bregitzer P (1992) Plant regeneration and callus type in barley: effects of genotype and culture medium. Crop Sci. 32: 1108-1112.

Bregitzer P, Campbell RD and Wu Y (1995) Plant regeneration from barley callus: effects of 2,4-dichlorophenoxyacetic acid and ohenylacetic acid. Plant Cell Tiss. Org. Cult. 43: 229-235.

Bregitzer P, Dahleen LS and Campbell RD (1998) Enhancement of plant regeneration from embryogenic callus of commercial barley cultivars. Plant Cell Rep. 17: 941-945.

Carvalho CHS, Bohorova N, Bordallo PN, Abreu LL, Valicente FH, Bressan W and Paiva E (1997) Type II callus production and plant regeneration in tropical maize genotypes. Plant Cell Rep. 17: 73-76.

Castillo AM, Egana B, Sanz JM and Cistué L (1998) Somatic embryogenesis and plant regeneration from barley cultivars grown in Spain. Plant Cell Rep. 17: 902-906.

Chang Y, Von Zitzewitz J, Hayes PM and Chen THH (2003) High frequency plant regeneration from immature embryos of an elite barley cultivar (Hordeum vulgare L. cv. Morex). Plant Cell Rep. 21: 733-738.

Chauhan M and Kothari SL (2004) Optimization of nutrient levels in the medium increases the efficiency of callus induction and plant regeneration in recalcitrant Indian barley (Hordeum vulgare L.) in vitro. In Vitro Cell Dev Biol-Plant 40: 520-527.

Chauhan H, Desai SA and Khurana P (2007) Comparative analysis of the differential regeneration response of various genotypes of Triticum aestivum, Triticum durum and Triticum dicoccum. Plant Cell Tiss. Org. Cult. 91: 191-199.

Cho MJ, Jiang W and Lemaux PG (1998) Transformation of recalcitrant barley cultivars through improvement of regenerability and decreased albinism. Plant Sci. 138: 229244.

Cho MS and Zapata FJ (1988) Callus formation and plant regeneration in isolated pollen culture of rice (Oryza sativa L. cv. Taipei 309). Plant Sci. 58: 239-244.

Cristea TO, Leonte C, Brezeanu C, Brezeanu M, Ambarus S, Calin M and Prisecaru M (2012) Effect of $\mathrm{AgNO}_{3}$ on androgenesis of Brassica oleracea L. anthers cultivated in vitro. African J. Biotech. 11(73): 13788-13795.

El-Itriby HA, Assem SK, Hussein EHA, Abdel-Calil FM and Madkour MA (2003) Regeneration and transformation of egyptian maize inbred lines via immature embryo culture and a biolistic particle delivery system. In Vitro Cellular and Develop Biology-Plant 39(5): 524-531.

Farshadfar E, Jamshidi B and Chehri M (2014) Assessment of immature embryo culture to select for drought tolerance in bread wheat. Int. J. Bio-Sci. 4(4): 194-203. 
Fernandez S, Michaux-Ferriere N and Coumans M (1999) The embryogenic response of immature embryo cultures of durum wheat (Triticum durum Desf): histology and improvement by AgNO3. Plant Growth Regul. 28: 147-155.

Ganeshan S, Chodaparambil SV, Baga M, Fowler DB, Huel P, Rossnagel B and Chibber RN (2006) In vitro regeneration of cereals based on multiple shoot induction from mature embryos in response to thidiazuron. Plant Cell Tiss. Org. Cult. 86: 63-73.

Gholami AA, Alavi SV, Majd A and Fallahian F (2013) Plant regeneration through direct and indirect somatic embryogenesis from immature seeds of citrus. Eur. J. Exp. Bio. 3(3): 307-310.

Goldestein CS and Kronstad WE (1986) Tissue culture and plant regeneration from immature embryo explants of barley (Hordeum vulgare). Theor. Appl. Genet. 71: 631636.

Gubišová M, Mihálik D and Gubiš J (2012) Optimization of barley mature embryo regeneration and comparison with immature embryos of local cultivars. Nova Biotechnol. Chim. 11(1): 57-62.

Gugsa L and Kumlehn J (2011) Somatic embryogenesis and massive shoot regeneration from immature embryo explants of Tef. vol 2011, Article ID 309731, 7 pages doi:10.4061/2011/309731.

Gürel F, Karakas O, Albayrak G and Ari S (2009) Regeneration capacity of mature embryo-derived callus in barley (Hordeum vulgare L.). Acta Biol. Hung. 60: 309-319.

Hanzel JJ, Miller JP, Brinkman MA and Fenods E (1985) Genotype and media effects on callus formation and regeneration in barley. Crop Sci. 25: 27-31.

Haque M and Islam SMS (2014) Enhancement of anther culture response by cold pretreatment and optimisation of media about two barley (Hordeum vulgare L.) genotypes derived from Bangladesh. As. Pac. J. Mol. Bio. Biotech. 22(1): 127-136.

Havrlentova M, Farago J and Nestakova M (2001) Regeneration of immature inflorescences of barley. In Vitro Cell Dev Biol-Plant 44: 157-159.

Huang X-Q and Wei Z-M (2004) High-frequency plant regeneration through callus initiation from mature embryos of maize (Zea mays L.). Plant Cell Rep. 22: 793-800.

Hunter CP (1987) Plant regeneration method. European Patent Application, No. 0245898 A2, p 8.

Hussein EHA, Madkour MA, Assem SK and Radwan AMA (2004) Embryogenic callus formation and plant regeneration from immature embryos of some barley genotypes (Hordeum vulgare L.). Arab J. Biotech. 7(1): 111-122.

Indra AP and Krishnaveni S (2009) Effect of hormones, explants and genotypes in in vitro culturing of Sorghum. J. Biochem. Tech. 1(4): 96-103.

Islam SMS (2000) Anther and microspore culture of wheat (Triticum aestivum L.). Ph.D. dissertation. University of Rajshahi, Bangladesh.

Islam SMS, Bari MA, Amin MN and Schmid JE (2001) In vitro plant regeneration through anther culture of eight wheat varieties. Plant Tissue Cult. Biotech. 11(1): 31-39. 
Islam SMS (2010) Effect of embryoids age, size and shape for improvement of regeneration efficiency from microspore-derived embryos in wheat (Triticum aestivum L.) Plant Omics J. 3(5):149-153.

Islam SMS and Tuteja N (2012) Enhancement of androgenesis by abiotic stress and other pretreatments in major crop species. Plant Sci. 182: 134-144.

Jakubeková M, Pretová A and Obert B (2011) Somatic embryogenesis and plant regeneration from immature embryo induced callus of Maize (Zea mays L.). J. Microbiol. Biotech. Food Sci. 1(4): 478-487.

Jha AK, Dahleen LS and Suttle JC (2007) Ethylene influences green plant regeneration from barley callus. Plant Cell Repor. 26(3): 285-290.

Jha P, Yadav CB, Anjaiah V and Bhat V (2009) In vitro plant regeneration through somatic embryogenesis and direct shoot organogenesis in Pennisetum glaucum (L.) R, Br. In Vitro Cell Dev Bio-Plant 45: 145-154.

Kabir KMR, Kwon S-W and Park Y-J (2013) Application of cobalt chloride and silver nitrate for efficient microspore culture of Brassica rapa ssp. Plant Tiss. Cult. Biotech. 23(1): 1-10.

Khatun R, Islam SMS and Bari MA (2010) Studies on plant regeneration efficiency through in vitro micropropagation and anther culture of twenty five rice cultivars in Bangladesh. J App. Sci. Res. 6(11): 1705-1711.

Klčová L, Havrlentová M and Faragó J (2004) Cultivar and environmental conditions affect the morphogenic ability of barley (Hordeum vulgare) scutellum derived calli. Biologia Bratislava 59(4): 501-504.

Kumar V, Parvatam G and Ravishankar GA (2009) $\mathrm{AgNO}_{3}$ a potential regulator of ethylene activity and plant growth modulator. Electron. J. Biotech. 12: 1-15.

Manivannan A, Kaul J, Singode A and Dass S (2010) Callus induction and regeneration of elite Indian maize inbreds. African J. Biotech. 9(44): 7446-7452.

Manoharan M and Dahleen LS (2002) Genetic transformation of the commercial barley (Hordeum vulgare L.) cultivar conlon by particle bombardment of callus. Plant Cell Rep. 21: 76-80.

Mordhorst AP and Lörz H (1993) Embryogenesis and development of isolated barley (Hordeum vulgare L.) microspores are influenced by the amount and composition of nitrogen sources in culture media. J. Plant Physiol. 142(4): 485-492.

Ogawa T, Fukuwa H and Ohkawa Y (1995) Plant regeneration through direct culture of isolated pollen grains in rice. Breed Sci. 45: 301-307.

Oldach K, Morgenstern A, Rother S, Girgi M, O'Kennedy M and Lörz H (2001) Efficient in vitro plant regeneration from immature zygotic embryos of Pearl millet [Pennisettum glaucum (L) R Br] and Sorgum bicolor (L) Moench. Plant Cell Rep. 20(5): 416-421.

Olsen FL (1987) Induction of microspore embryogenesis in cultured anthers of Hordeum vulgare. The effects of ammonium nitrate, glutamine and asparagine as nitrogen sources. Carlsberg Res. Commun. 52: 393-404. 
Orton TJ (1979) A quantitative analysis of growth and regeneration from tissue culture of Hordeum vulgare, H. jubatum and their interspecific hybrid. Envn. Expt. Bot. 19: 319 335.

Ou'edraogo J'T, St-Pierre CA, Collin J, Rioux S and Comeau A (1998) Effect of amino acids, growth regulators and genotype on androgenesis in barley. Plant Cell Tiss. Org. Cult. 53: 59-66.

Pola S, Mani NS and Ramana T (2009) Long-term maintenance of callus cultures from immature embryo of Sorghum bicolor. World J. Agri. Sci. 5(4): 415-421.

Pourmohammad A (2013) The response of embryo explant to tissue culture in wheat varieties. Scientific J. Crop Sci. 2(9): 133-135.

Przetakiewicz A, Orczyk W and Nadolska-Orczyk A (2003) The effect of auxin on plant regeneration of wheat, barley and triticale. Plant Cell Tiss. Org. Cult. 73: 245-256.

Pua EC, Deng $\mathbf{X}$ and Koh ATC (1999) Genotypic variability of de novo shoot morphogenesis Brassica oleracea in vitro in response to ethylene inhibitors and Putrescine. J. Plant Physiol. 155(4-5): 598-605.

Purnhauser L, Medgysey P, Czako M, Dix JP and Marton L (1987) Stimulation of shoot regeneration in Triticum aestivum and Nicotiana plumbaginifolia via tissue cultures using the ethylene inhibitor silver nitrate. Plant Cell Rep. 6(1): 1-4.

Reddy BO, Giridhar P and Ravishankar GA (2001) In vitro rooting of Decalepis hamiltonii Wight and Arn., an endangered shrub by auxins and root promoting agents. Current Sci. 81(11): 1479-1481.

Sah SK and Kaur A (2013) Genotype independent tissue culture base line for high regeneration of japonica and indica rice. Res. J. Biotech. 8: 96-101.

Sahrawat AK, Chand S (2004) High frequency plant regeneration from coleoptile tissue of barley (Hordeum vulgare L.). Plant Sci. 167: 27-34.

Sharma VK, Hänsch R, Mendel RR and Schulze J (2004) A highly efficient plant regeneration system through multiple shoot differentiation from commercial cultivars of barley (Hordeum vulgare L.) using meristematic shoot segments excised from germinated mature embryos. Plant Cell Rep. 23: 9-16.

Sharma A, Kumar V, Giridhar P and Ravishankar GA (2008) Induction of in vitro flowering in Capsicum frutescens under the influence of silver nitrate and cobalt chloride and pollen transformation. Electronic J. Biotech. 11(2): 1-6.

Siddique AB, Ara I, Islam SMS and Tuteja N (2014) Effect of air desiccation and salt stress factors on in vitro regeneration of rice (Oryza sativa L.). Ms. Ref. No.: 2014PSB281, Plant Signaling Behavior.

Silva AS, Luz JMQ, Rodrigues TM, Bittar CA and Lino LO (2011) Callus induction and embryo regeneration in Coffea arabica L. anthers by silver nitrate and ethylene. Rev Ciênc Agron 42(4): 921-929.

Sunandakumari C, Martin KP, Chithra M and Madhusoodanan PV (2004) Silver nitrate induced rooting and flowering in vitro on rare rhoeophytic woody medicinal plant, Rotula aquatica Lour. Indian J. Biotech. 3(3): 418-421. 
Taji AM, Dodd WA and Williams RR (1992) Plant tissue culture practices. University of New England, Armidale, NSW.

Vasil V and Vasil IK (1987) Formation of callus and somatic embryos from protoplasts of a commercial hybrid of maize (Zea mays L.). Theor. Appl. Genet. 73: 789-793.

Ward KA and Jordan MC (2001) Callus formation and plant regeneration from immature and mature embryos of rye (Secale cereale L.). In Vitro Cellular and Developmental Biology - Plant 37: 361-368.

Wu LM, Wei YM and Zheng YL (2006) Effects of silver nitrate on the tissue culture of immature wheat embryos. Russian J. Plant Physiol. 53(4): 530-534.

Xu ZH and Sunderland N (1981) Glutamine, inositol and conditioning factor in the production of barley pollen callus in vitro. Plant Sci. Lett. 23: 161-168.

Yu Y, Wang J, Zhu M-L and Wei Z-M (2008) Optimization of mature embryo-based high frequency callus induction and plant regeneration from elite wheat cultivars grown in China. Plant Breed. 127: 249-255.

Zaman MA, Manjur ABMK, Ahmed M and Islam MM (2010) Effect of 2,4-D on callus induction and subsequent morphogenesis in mature Chickpea (Cicer arietinum L.) embryo culture. In: Role of Biotechnology in Food Security and Climate Change. Islam AS, Haque MM, Sarker RH and Hoque MI (Eds). Proc. Sixth Intl. Plant Tissue Cult. \& Biotech. Conf., December 3-5, 2010, Bangladesh Assoc. Plant Tiss. Cult. Biotech Dhaka, Bangladesh pp. 53-58.

Zhu Y, Zhao F and Zhao D (2011) Regeneration and transformation of a maize elite inbred line via immature embryo culture and enhanced tolerance to a fungal pathogen Exserohilum turcicum with a balsam pear class I chitinase gene. Afr. J. Agri. Res. 6(7): 1923-1930. 